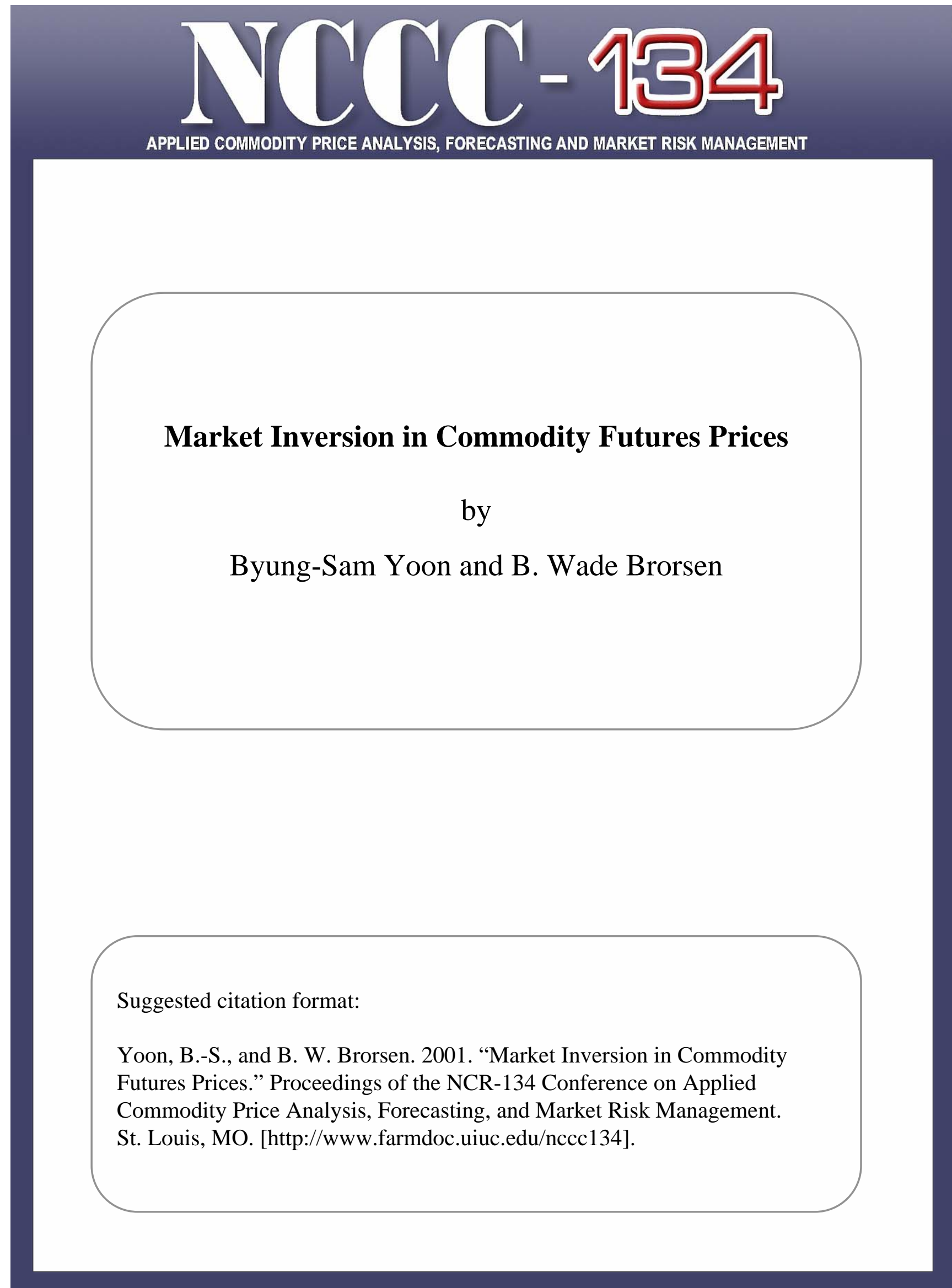




\title{
Market Inversion in Commodity Futures Prices
}

\author{
by
}

\section{Byung-Sam Yoon}

\section{B. Wade Brorsen}

Paper presented at the NCR-134 Conference on Applied Commodity Price Analysis, Forecasting, and Market Risk Management

St. Louis, Missouri, April 23-24, 2001

Copyright 2001 by Byung-Sam Yoon and B. Wade Brorsen. All rights reserved. Readers may make verbatim copies of this document for non-commercial purposes by any means, provided that this copyright notice appears on all such copies.

Byung-Sam Yoon is a Ph.D. graduate and B. Wade Brorsen is a regents professor and Jean \& Patsy Neustadt Chair (brorsen@okstate.edu) in the Department of Agricultural Economics at Oklahoma State University. 


\title{
Market Inversion in Commodity Futures Prices
}

\begin{abstract}
As opposed to a normal market, an inverted market has a negative price of storage or spread. Market inversions in nearby spreads rarely occur during early months of the crop year since stocks are usually abundant after harvest. However, market inversions frequently occur when the spreads are observed across crop years near the end of the crop year. The regressions of spreads on the logarithm of U.S. quarterly stocks show that there exists a positive relationship between the spread and the level of stocks, and further implies that when stocks are scarce, markets will be inverted. Simulations are conducted to determine whether a market inversion is a signal to sell the stocks. The results of the paired-difference tests reveal that as the crop cycle advances towards the end of the crop year, market inversions clearly reflect the market's signal to release stocks in anticipation of new crop supplies. The regressions of actual returns to storage on predicted returns to storage clearly show that a market inversion is a signal to sell. The results support the behavioral finance hypothesis that producers are choosing to hold excess stocks because of some type of biased expectations.
\end{abstract}

Key words: convenience yield, cost of carry, market inversion, negative price of storage, risk premium.

\section{Introduction}

A principal theory of futures markets tells that futures prices for storable commodities should be higher than spot prices by the carrying charges. Carrying charges represent the cost of storage, primarily warehousing and insurance cost plus interest foregone. If the spot price is too low relative to the futures price, a cash-and-carry arbitrage opportunity arises and the trader who engages in arbitrage reaps a riskless profit. Thus, in a normal market, a futures price spread is limited by arbitrage to the full cost of carry.

However, this theory is not always supported by empirical evidence. A puzzling phenomenon in actual commodity markets is that processors and merchandisers routinely hold inventories in the face of inverse carrying charges. In an inverted market, a commodity's price for future delivery is below the price for immediate delivery and intertemporal arbitrage conditions fail to apply. Under market inversion, since the price spread in futures markets fails to cover commodity-holding costs, stockholders apparently gain negative returns to storage.

This aspect of commodity markets was first noticed by Working (1934), while studying the price relationships between old and new-crop wheat futures at Chicago. He observes that nationwide wheat stocks are held even when the intertemporal spread (price 
of storage) is inverted, and argues that the price of storage is dependent upon the aggregate level of stocks. Later, Working's findings were represented by the supply-ofstorage curve, which shows that the farther the spot/futures spreads are below full carrying charges, the less amount of stocks are held.

Traditionally, there were two major, but contradictory, theories explaining the phenomenon of market inversion. The risk premium theory of Keynes (1930) holds that speculators must be compensated for their risk taking by hedgers in the form of a risk premium. In markets where speculators are predominantly short, the futures price is biased downward relative to the expected future spot price by the amount of a risk premium. In contrast, the convenience yield theory, first employed by Kaldor (1939), maintains that when processors and merchandisers hold stocks readily available at hand, they receive some non-monetary benefits that do not accrue to the holders of futures contracts.

Recently, alternative explanations for market inversions have been suggested, notably in articles by Wright and Williams; Benirschka and Binkley; and Brennan, Williams, and Wright. According to their view, the apparent relationship between market inversions and return to storage is caused by mismeasurement. Wright and Williams (1989), and Brennan, Williams, and Wright (1997) argue that market inversions may occur when the stocks of very similar but economically distinct commodities in terms of grade or location are aggregated into a composite while the prices for the commodities are represented by a single price. Brennan, Williams, and Wright also suggest that the market inversion may be caused by the probability of a stock out. Benirschka and Binkley (1995) argue that "storage at a loss" illusion exists because the opportunity costs of storage are overestimated by using grain prices at the central market, not at the storage locations. Frechette and Fackler (1999) examined Benirschka and Binkley's proposition, that is, the location of stocks matters in the intertemporal price relationships of storable commodities, for the U.S. corn market and found mixed empirical support.

A market inversion appears to be a situation where the market is begging producers to sell, yet many continue to store their stocks. Behavioral finance (Kahneman, et al., 1982; Kahneman and Riepe, 1998) offers an alternative explanation that producers are choosing to hold excess stocks because of some type of biased expectations. Hurt (1987), for example, argues that a market inversion is a signal to sell.

The studies cited above rationalize the market inversion well, but have not provided measurements of the frequency of market inversions or evaluated marketing strategies based on market inversions. The primary objective of the study is to determine the optimal marketing strategy when agricultural commodity futures markets are inverted. First, the frequency of market inversions in corn, soybeans, and wheat markets will be determined by comparing nearby futures price spreads with the contemporaneous costs-of-carry. Then, regression analysis will be used to determine the situations in which 
the market inversions occur. Finally, simulations will be conducted to determine the optimal marketing strategy when markets are inverted.

\section{Theory}

Market inversion is commonly known as backwardation in British terms. ${ }^{1}$ It describes a market situation in which the spot price exceeds the futures price or a nearby futures price exceeds a distant futures price.

The theory of the price of storage that explains intertemporal price relationships between spot and futures with respect to the cost of carrying a commodity was first proposed by Kaldor (1939). Following Kaldor, Working (1948, 1949), Brennan (1958, 1991), Telser (1959), Fama and French $(1987,1988)$, and Heaney (1998) have elaborated on the theory of storage.

The theory of the price of storage explains the price difference between spot and futures in terms of interest foregone in storing a commodity (the opportunity cost of storage), physical storage costs, risk premium, and convenience yield for holding stocks. Let $F(t, T)$ be the futures price at time $t$ for delivery of a commodity at time $T, S(t)$ the spot price at time $t, S(t) R(t, T)$ the interest forgone during storage, $W(t, T)$ the physical storage costs, $P(t, T)$ the risk premium, and $C(t, T)$ the convenience yield, then the price of storage (basis), $F(t, T)-S(t)$, is defined as:

$$
F(t, T)-S(t)=S(t) R(t, T)+W(t, T)+P(t, T)-C(t, T) .
$$

The price of storage or basis, $F(t, T)$ - $S(t)$, can be interpreted as the return to storage from time period $t$ to $T(t<T)$, i.e., the return from purchasing the commodity at $t$ and selling it for delivery at $T$. The interest forgone, $S(t) R(t, T)$, is the opportunity cost of holding stocks, i.e., the opportunity cost of investing cash in the commodity stock now rather than using a futures contract. The physical cost of storage, $W(t, T)$, is the sum of rent for storage space, handling or in-and-out charges, insurance, transport, etc. As the quantity of stocks held by a firm increases, the physical cost of storage increases. However, the marginal physical cost of storage for an additional unit of stocks is approximately constant for a wide range of stocks less than total storage capacity. Beyond the level at which the total storage capacity is almost fully utilized, the marginal physical cost of storage will rise sharply because of the large fixed costs required to construct additional storage facilities.

The risk premium, $P(t, T)$, is the compensation for the risk of monetary loss on the stocks held. Brennan (1958) incorporated the risk premium originated with Keynes and Hicks into the components of the cost of storage. He argues that the market must offer a risk premium to encourage firms to hold stocks because the risk of loss of inventory value constitutes the net cost of storage. When stock levels are low, the risk of a commodity losing its value is small. However, as stock levels increase, the risk of loss of inventory value also increases, potentially up to the critical point at which a firm's credit position is seriously endangered. The higher the level of stocks, the more risky the 
investment in stocks, and the greater the compensation required for holding the stocks. Thus, the risk premium (or risk aversion factor denoted by Brennan (1958)) is assumed to be an increasing function of stocks. It rises with increases in stocks at an increasing rate;

$\frac{\partial P}{\partial X}>0$ and $\frac{\partial^{2} P}{\partial^{2} X}>0$, where $X$ is the amount of stocks held.

The convenience yield, $C(t, T)$, refers to a stream of implicit benefits that accrues to the owner of a physical stock but not to the owner of a contract for future delivery. Stockholders earn the convenience yield because stocks on hand allow them to respond more flexibly and efficiently to unexpected supply and demand shocks. Where stocks are held, regular customer demands can be met, and sudden and unexpected increases in demand can be accommodated without disrupting production schedules. The convenience yield may be thought of as a negative price of storage in that it reflects the benefits rather than the cost of stockholding. These benefits are most significant when stocks are scarce. When stocks are abundant, the convenience yield approaches zero because the scarcity value of stocks is minimal. Empirical evidence presented by Working $(1949,1949)$, Telser (1958), Fama and French $(1987,1988)$, and Brennan (1991) also suggest that the convenience yield is a decreasing (convex) function of stocks. It declines with increases in stocks but at a decreasing rate; $\frac{\partial C}{\partial X}<0$ and $\frac{\partial^{2} C}{\partial^{2} X}>0$, where $X$ is the amount of stocks held.

The theory of the price of storage also applies to the relationships between two futures contracts of different delivery months. The price of storage or spread between the nearby and distant futures contracts is defined as:

$$
F(t, D)-F(t, N)=F(t, N) R(N, D)+W(N, D)+P(N, D)-C(N, D), \quad D>N,
$$

where $F(t, D)$ is a distant futures price quoted at time $t$, maturing at time $D, F(t, N)$ is a nearby futures price quoted at time $t$, maturing at time $N(D>N)$. Thus, $F(t, D)-F(t, N)$ is the market spread or the return to storage from time period $N$ to $D . F(t, N) R(N, D)$ is the opportunity cost of holding stocks for the period $N$ to $D . W(N, D)$ is the physical costs of storage from time $N$ to $D . P(N, D)$ is the risk premium for holding stocks for the period $N$ to $D$. $C(N, D)$ is the convenience yield arising from stockholding from time $N$ to $D$.

In equations (1) and (2), two of the components that determine the price of storage, i.e., risk premium and convenience yield, are not directly observable. When stocks are sufficiently low, the theory of the price of storage predicts a negative price of storage (negative spread) or market inversion since the convenience yield overwhelms the sum of interest forgone, storage costs and risk premium. On the other hand, if the stock levels are sufficiently high, the convenience yield is negligible and the price of storage (spread) is essentially the sum of interest forgone, storage costs and risk 
premium. Here, one testable hypothesis generated by the theory of the price of storage is that markets will be inverted when stocks are low.

When markets are inverted, a negative price of storage (negative spread) can be interpreted as a market signal that encourages firms to release their stocks into consumption channels. Under market inversion, it is best for stockholders to sell their stocks now since storage only occurs at a very high opportunity cost. Another testable hypothesis from this argument is that producers will receive highest expected returns by selling stocks rather than storing when markets are inverted.

\section{Data}

The agricultural commodities selected for the analysis of market inversion in futures prices are corn, soybeans, and wheat. Futures prices from the Chicago Board of Trade are obtained from the Annual Report of the Board of Trade of the City of Chicago and from a computer database compiled by Technical Tools, Inc. Futures price is the closing price of the corresponding contract month observed on the first trading day of each calendar month. The sample period extends from 1957 through 1999 for corn, and from 1958 through 1999 for wheat and soybeans. A long time series is needed because market inversions occur infrequently. However, before the first year of the sample periods, only nearby futures contracts were reported and a lot of observations, for example, March futures prices, were missing. Thus, this study could not go back farther in time.

For the same periods with the futures price series, monthly cash grain prices are obtained from National Agricultural Statistics Service (NASS) of the U.S. Department of Agriculture. The cash prices are U.S. monthly average prices received by farmers and denoted in dollars per bushel. The average price is the open-market price resulted from dividing the total dollars received by all farmers by the total quantity sold. U.S. monthly average prices are computed by weighting monthly prices by the estimated percentage of monthly sales during the month by State. U.S. quarterly grain stocks, and grain supply and demand data are also from National Agricultural Statistics Service of the U.S. Department of Agriculture.

The cost-of-carry or carrying charge from the perspective of off-farm, commercial storage consists of two components: physical storage costs charged by elevators and the interest opportunity cost. Commercial grain storage rates over the 1970-1999 period, characterized as variable cost only, were obtained from Oklahoma Cooperative Extension Service at Oklahoma State University. The prevailing commercial grain storage rates in recent years are commonly cited as 2.5 to 2.6 cents per bushel per month (Jackson, Irwin, and Good, 1997; Kastens and Dhuyvetter, 1999). To create a historical time series of storage costs for the period 1957 through 1969, the average commercial grain storage cost of 2.55 cents per bushel per month is deflated using the producer price index (PPI) from Bureau of Labor Statistics. The U.S. prime loan rates from the Federal Reserve Bank of St. Louis are used to calculate the opportunity or interest costs for stored grain. 


\section{Procedures}

The market spread, defined as the difference between two futures prices can be constructed within and across crop years. The spread between futures prices for nearby and distant delivery dates is defined by

$$
S(t)=F(t, D)-F(t, N)
$$

where $S(t)$ represents the spread between two futures prices observed at time $t, F(t, D)$ represents the futures price of a distant delivery month at time $t$, and $F(t, N)$ represents the futures price of a nearby delivery month at time $t$. For corn, the December-March spread in December, the March-May spread in January, February, and March, the MayJuly spread in April and May, and the July-September spread in June and July are examined. In futures contract months for corn, December represents harvest, March represents preplanting, May represents planting, July represents the middle of the growing season, and September represents the late growing season or early harvest. For soybeans, the November-January spread in November, the January-March spread in December and January, the March-May spread in February and March, the May-July spread in April and May, the July-August spread in June and July, and the AugustSeptember spread in August are examined. For wheat, the July-September spread in July, the September-December spread in August and September, the December-March spread in October, November, and December, and the Mar-May spread in January, February, and March are examined.

The cost of carry or carrying charge necessary to carry the commodity from the nearby delivery date to the distant delivery date is defined by

$$
C C(t,(N, D))=F(t, N)\left[e^{r(N, D)}-1\right]+W(N, D),
$$

where $C C(t,(N, D))$ is the carrying charges from $N$ to $D$ at time $t, F(t, N)$ is a nearby futures price quoted at time $t, e^{r(N, D)}$ is continuously compounded rate of return for the period $N$ to $D$, and $W(N, D)$ is the physical cost of storage from time $N$ to $D$.

Using equations (3) and (4), this study measures the extent to which the market spread between futures prices for nearby and distant delivery dates falls below full carrying charges. The degree of being below full carry is classified into six categories based on the percentage of market spread to the cost of carry or carrying charge. The frequency of market inversions is identified using information on the percentage of market spread to the cost of carry.

An empirically testable hypothesis drawn from equations (1) and (2) is that when stocks are low, the price of storage (basis or spread) becomes negative and markets will 
be inverted. To determine the relationship between the spread and the level of stocks, market spreads are regressed on the logarithm of U.S. quarterly stocks ${ }^{2}$ :

$$
\text { Spread }_{t}=\beta_{0}+\beta_{1} \ln \left(Q S_{t}\right)+\varepsilon_{t} \text {, }
$$

where $\ln \left(Q S_{t}\right)$ is the natural logarithm of U.S. quarterly stocks and $\varepsilon_{t}$ is the error term. Each quarterly stock estimate is analyzed with respect to the spread corresponding to the nearest futures contract. For example, December stocks for corn are compared to December-March spreads on December 1, March stocks are compared to Mar-May spreads on March 1, and June stocks are compared to July-September spreads on June 1. Since the quarterly grain stocks estimates are based on the stock levels as of the first day of December, March, June, and September, the spread-stock relationships are synchronous. A similar regression was also used in coffee and cocoa futures markets (Thompson, 1986), and energy futures markets (Cho and McDougall, 1990). The major weakness of this regression is that the two variables included in the regression have time trends and show some degree of autocorrelation. Spreads tend to grow due to inflation and U.S. quarterly stocks tend to increase due to increases in crop production over the years. Regressing one trending variable against another trending variable may result in a too high estimated regression coefficient.

When markets are inverted, stockholders apparently gain negative returns to storage due to inverse carrying charges. Thus, the recommended strategy is 'sell the stocks'. To determine whether a market inversion is a signal to sell stocks, simulations are conducted.

Simulation strategies considered are cash sale, unhedged storage, and hedged storage. To compare the results of three strategies, net returns to each strategy are evaluated at a future date, i.e., when the hedge for a hedged storage is lifted. The hedge is lifted on the first trading day of the delivery month for the distant futures contract. For example, in the Dec-Mar spread for corn observed on December 1, the hedge initiated on December 1 is finally lifted on March 1. For this study, the producer is assumed to produce 5,000 bushels of corn, soybeans, or wheat. The simulation strategies are summarized as follows:

1. Cash sale: At the beginning of each calendar month, if the percentage of a nearby spread to the cost of carry falls below zero or a predetermined level, e.g., $0.25 \%$, the producer will sell 5,000 bushels of grain. The cash price examined in this study is U.S. average prices received by farmers during the month the cash commodity is sold. Interest is accrued to the proceeds from the cash sale at a continuously compounding rate. Thus, net returns to cash sale is calculated as the sum of cash price sold and the accrued interest. 
2. Unhedged storage: This strategy involves storing the cash commodity without using any hedging instrument. Returns to unhedged storage are determined by the levels of cash prices. This strategy is used as the benchmark against which cash sale and hedged storage are evaluated.

3. Hedged storage: At the beginning of each calendar month, if the percentage of a nearby spread to the cost of carry falls below zero or a predetermined level, e.g., $0.25 \%$, the producer will sell one lot $(5,000$ bushels) of distant futures contract. On the first trading day of the delivery month for the distant futures contract, the hedge is lifted and the cash commodity is sold. Returns to hedged storage are dependent upon changes in the cash price relative to changes in the futures price. Futures transaction costs including brokerage fees and liquidity costs are assumed to be 1.5 cents per bushel or 75 dollars per contract.

To compare the net returns to three marketing strategies, paired-differences tests are conducted. The paired $t$-tests are based on the following three pairs of strategies: (1) cash sale vs. unhedged storage (CS-US); (2) cash sale vs. hedged storage (CS-HS); and (3) unhedged storage vs. hedged storage (US-HS).

As with all simulations, an adequate number of observations to fully specify the distribution of net returns to each strategy are a real matter of concern. Since the true market inversions with negative spreads are expected to rarely occur during early months of the crop year, the number of observations in this study may not be large enough to meet the desired number of observations from statistical sampling theory. Thus, this study relaxes the decision rule for market inversion such that market spread as a percent of the cost-of-carry below 0.25 is considered as a market inversion.

As another way to deal with a small sample problem for the monthly observations, this study pools the monthly observations by commodity. With the aggregated data, this study regresses the actual returns to storage (unhedged and hedged) on the predicted returns to storage and a set of dummies representing the distance to harvest. The actual returns to unhedged (hedged) storage are computed by subtracting the returns to cash sale from the returns to unhedged (hedged) storage, and the predicted returns to storage are the corresponding futures price spreads.

\section{Results}

Table 1 reports summary statistics for the market spreads of three commodities. Since the length of spreads is not of equal time intervals, they are standardized to reflect equal spread length of one month. To calculate the mean value of spreads per month, spreads are adjusted by dividing by the number of months between the near and distant futures. For example, the mean of Dec-Mar spread for corn is adjusted by dividing by the spread interval of three months. To measure the volatility of the spreads per month, 
spreads are adjusted by dividing by the square root of the spread length and subsequently computing the standard deviation of the adjusted spreads.

From Table 1, it can be observed that there is a seasonal pattern in the mean of spreads for all three commodities. In general, the mean value of the spreads declines from the beginning of the crop year to the end of the crop year. Mean spreads are greatest after harvest or during early months of the crop year, then decrease to minimums and even go negative on average during the growing season or just before the new harvest. Negative spreads or inverse carrying charges are consistently observed in the July-September spread for corn, the July-August and August-September spreads for soybeans, and the March-May spread for wheat. For corn and soybeans, the July futures contract is the last consistently old crop contract. The September futures contract may be a new crop contract if harvest starts early enough and thus is often treated as a transitional contract between old and new crop. The results confirm that in grain markets, market inversions are most frequent between the last of the old-crop delivery months and the first of the new crop delivery months, i.e., across crop years. Contrary to the behavior of mean spreads, the volatility of the spreads has a tendency to increase from harvest to the full growing season of the crop year. For example, the standard deviation of the Dec-Mar spread for corn in December is 2.42, while the standard deviation of the Jul-Sep spread for corn in July is 15.00 .

Table 2 presents summary statistics for spreads as percent of contemporaneous costs-of-carry. The mean of the spread to cost-of-carry ratio falls below one for all spreads, indicating that grain markets on average are below full carry. The highest ratio is 0.96 in the September-December wheat futures spread observed in September. Figures 1, 2 , and 3 present the graphs for selected spreads as a percent of contemporaneous costs-ofcarry for corn, soybeans, and wheat respectively.

Table 3 exhibits the occurrences of spreads as a percent of contemporaneous costs-of-carry at various levels. Market inversions in nearby spreads rarely occur during early months of the crop year. During 3 months after harvest, market inversions occur only 2 to $7 \%$ of the time. The theory of the price of storage also predicts that negative spreads between two new crop futures contracts are less likely to occur because stocks are usually plentiful after harvest, and thus convenience yields are small. On the contrary, the number of observations with the percent of cost-of-carry greater than one, i.e., above full carry, is relatively large. This implies that there exist substantial cash-and-carry arbitrage opportunities because the cost of carry is too low relative to the market spread. One reason for being above full carry is that the fixed cost component of grain storage costs is missed in calculating the cost-of-carry, and thus the cost-of-carry is underestimated. Another possible reason is that market spreads may reflect risk premia with buildup in stocks after new-crop harvest or during early months of the crop year.

Table 4 reports the regression results for spreads against U.S. quarterly grain stocks. The $\mathrm{R}^{2}$ values are very low, ranging from 0.01 in the Mar-May spread for wheat 
to 0.20 in the Sep-Dec spread for wheat. The slope terms for the first two spreads in corn and soybeans are statistically significant at the 5\% level. The slope term for the Sep-Dec spread in wheat is statistically significant at the 5\% level and that for the Dec-Mar spread is significant at the $10 \%$ level. There is a tendency for regressions during early months of the crop year to fit better than the regressions towards the end of the crop year, suggesting that the spread-stock relationship is more pronounced when stocks are abundant. Overall, the results support that there is a positive relationship between the spread and the level of stocks, and thus when the stocks are scarce, the spread becomes negative and markets are inverted.

Table 5 reports the results of simulations for corn when markets are inverted, and Table 6 reports the results for the corresponding paired-differences tests. ${ }^{3}$ The results of paired-differences tests show that net returns to cash sale are greater than that of unhedged storage or hedged storage after May. For the Jul-Sep spread in July, returns to cash sale are higher than returns to both unhedged storage and hedged storage. Specifically, returns to cash sale are higher than returns to unhedged storage and hedged storage by 14.07 cents and 10.72 cents respectively. Given the fact that the full cost-ofcarry was not covered on average, the results were expected.

The results from simulations when markets are inverted show that as the crop cycle advances towards the end of the crop year, market inversions clearly reflect the market's signal to release stocks in anticipation of new crop supplies. However, it is not conclusive whether a market inversion is a signal to sell during early months of the crop year due to the low frequency of market inversions.

Table 7 presents the regression results for actual returns to storage against predicted returns to storage. There exists a positive relationship between actual returns to storage and predicted returns to storage except the unhedged storage for wheat. The result for wheat may come from the difference in crop variety. While the wheat futures contract traded on the Chicago Board of Trade is based on soft red winter wheat, U.S. monthly cash prices aggregate all varieties and qualities. The results suggest that as predicted returns to storage, i.e., spreads, get smaller or even go negative, the actual returns to storage decreases, and thus support the argument that a market inversion is a signal to sell.

\section{Conclusions}

As opposed to a normal market, an inverted market has a negative price of storage or spread. Futures price spreads for corn, soybeans, and wheat exhibit a seasonal pattern. In general, mean spreads gradually decline from the start of the crop year and even go negative on average at the end of the crop year or just before the new harvest. In contrast, the volatility of spreads measured by the standard deviation of spreads has a tendency to increase from harvest to the full growing season of the crop year. The spreads as percent of contemporaneous costs of carry are less than one on average, indicating that grain markets on average are below full carry. 
Market inversions in nearby spreads rarely occur during early months of the crop year since stocks are usually abundant after harvest. At 3 months after harvest, market inversions occur only 2 to $7 \%$ of the time. However, market inversions become pronounced when the spreads are observed across crop years at the end of the crop year or just before the new harvest. The regressions of spreads on the logarithm of U.S. quarterly stocks show that there exists a positive relationship between the spread and the level of stocks, and further implies that when stocks are scarce, markets will be inverted.

A market inversion appears to be a situation where the market encourages producers to release their stocks, yet many continue to store their grain. The simulations were conducted to determine whether a market inversion is a signal to sell the stocks. The results of the paired-differences tests reveal that as the crop cycle advances towards the end of the crop year, market inversions clearly reflect the market's signal to release stocks in anticipation of new crop supplies. The regressions of actual returns to storage on predicted returns to storage clearly show that a market inversion is a signal to sell. The results support the behavioral finance hypothesis that producers are choosing to hold excess stocks because of some type of biased expectations. 


\section{Footnotes}

1. The term "backwardation" used here has a different meaning than "normal backwardation." The theory of normal backwardation originated with Keynes (1930) and holds that the futures price is less than the expected future spot price due to a risk premium, and that the futures price should rise over time to equal the expected future spot price at expiration. As opposed to normal backwardation, "contango" refers to a price process in which the futures price falls over the life of the contract.

2. Extensive literature deals with the relationship between the price of storage (spread) and the level of stocks. With the difficulty in defining and accurately measuring the relevant inventory, a major difference among the studies lies in the measurement of the level of stocks. Telser (1958) showed that the price of storage is determined by the total marketable stocks rather than the total level of existing stocks. Weymar (1966) stressed that the expected level of stocks between two futures' time periods is more important than the current level of stock for the determination of the price of storage for two distant futures contracts. Gray and Peck (1981) demonstrated that the price of storage is determined by the current stocks readily available for delivery, rather than by the total level of current stocks.

3. The authors have also conducted the same simulations for soybeans and wheat. The findings from such simulations using soybeans and wheat are entirely consistent with the results presented here. 
Table 1: Summary Statistics for Futures Price Spreads, 1957-1999

\begin{tabular}{|c|c|c|c|c|c|c|c|}
\hline Commodity & Month & Spread & $\begin{array}{l}\text { No. } \\
\text { Obs. }\end{array}$ & Mean & $\begin{array}{l}\text { Standard } \\
\text { Deviation }\end{array}$ & Minimum & Maximum \\
\hline \multirow{8}{*}{ Corn } & December & Dec-Mar & 43 & 2.24 & 2.42 & -0.75 & 18.25 \\
\hline & January & Mar-May & 43 & 2.34 & 1.91 & -2.00 & 12.25 \\
\hline & February & Mar-May & 43 & 2.27 & 2.64 & -9.88 & 13.00 \\
\hline & March & Mar-May & 43 & 2.47 & 2.94 & -6.50 & 14.75 \\
\hline & April & May-Jul & 43 & 1.39 & 2.94 & -12.75 & 12.25 \\
\hline & May & May-Jul & 43 & 0.96 & 3.80 & -21.75 & 11.50 \\
\hline & June & Jul-Sep & 43 & -2.84 & 10.42 & -77.25 & 9.25 \\
\hline & July & Jul-Sep & 43 & -2.29 & 15.00 & -122.75 & 31.25 \\
\hline \multirow{10}{*}{ Soybeans } & November & Nov-Jan & 42 & 4.10 & 4.77 & -3.00 & 29.50 \\
\hline & December & Jan-Mar & 42 & 3.74 & 4.69 & -4.75 & 33.25 \\
\hline & January & Jan-Mar & 42 & 3.79 & 4.48 & -4.13 & 27.50 \\
\hline & February & Mar-May & 42 & 3.15 & 5.52 & -23.13 & 26.00 \\
\hline & March & Mar-May & 42 & 3.37 & 6.38 & -37.00 & 24.75 \\
\hline & April & May-Jul & 42 & 2.50 & 5.40 & -22.25 & 25.50 \\
\hline & May & May-Jul & 42 & 1.42 & 11.14 & -80.88 & 23.75 \\
\hline & June & Jul-Aug & 37 & -5.43 & 18.47 & -98.50 & 7.25 \\
\hline & July & Jul-Aug & 37 & -1.57 & 11.13 & -51.00 & 15.00 \\
\hline & August & Aug-Sep & 37 & -11.01 & 24.80 & -128.00 & 10.00 \\
\hline \multirow{9}{*}{ Wheat } & July & Jul-Sep & 42 & 2.63 & 3.35 & -6.00 & 19.50 \\
\hline & August & Sep-Dec & 42 & 3.14 & 4.15 & -14.25 & 31.00 \\
\hline & September & Sep-Dec & 42 & 3.38 & 4.26 & -6.00 & 29.50 \\
\hline & October & Dec-Mar & 42 & 2.13 & 4.46 & -15.00 & 25.25 \\
\hline & November & Dec-Mar & 42 & 1.90 & 5.31 & -18.50 & 25.25 \\
\hline & December & Dec-Mar & 42 & 1.75 & 5.74 & -16.00 & 30.75 \\
\hline & January & Mar-May & 42 & -2.34 & 7.66 & -29.50 & 10.50 \\
\hline & February & Mar-May & 42 & -2.20 & 8.44 & -37.50 & 15.25 \\
\hline & March & Mar-May & 42 & -0.99 & 9.07 & -44.25 & 13.50 \\
\hline
\end{tabular}


Table 2: Summary Statistics for Spreads as a Percent of Contemporaneous Costs-ofCarry, 1957-1999

\begin{tabular}{|c|c|c|c|c|c|c|c|}
\hline Commodity & Month & Spread & $\begin{array}{l}\text { No. } \\
\text { Obs. }\end{array}$ & Mean & $\begin{array}{l}\text { Standard } \\
\text { Deviation }\end{array}$ & Minimum & Maximum \\
\hline \multirow{8}{*}{ Corn } & December & Dec-Mar & 43 & 0.77 & 0.32 & -0.06 & 1.60 \\
\hline & January & Mar-May & 43 & 0.79 & 0.38 & -0.51 & 1.54 \\
\hline & February & Mar-May & 43 & 0.76 & 0.64 & -2.46 & 1.73 \\
\hline & March & Mar-May & 43 & 0.86 & 0.58 & -0.96 & 1.91 \\
\hline & April & May-Jul & 43 & 0.53 & 0.57 & -1.17 & 1.71 \\
\hline & May & May-Jul & 43 & 0.40 & 0.72 & -1.83 & 1.80 \\
\hline & June & Jul-Sep & 43 & -0.71 & 1.55 & -6.69 & 1.10 \\
\hline & July & Jul-Sep & 43 & -0.53 & 2.02 & -9.78 & 3.72 \\
\hline \multirow{10}{*}{ Soybeans } & November & Nov-Jan & 42 & 0.81 & 0.43 & -0.26 & 1.66 \\
\hline & December & Jan-Mar & 42 & 0.71 & 0.39 & -0.38 & 1.44 \\
\hline & January & Jan-Mar & 42 & 0.70 & 0.41 & -0.90 & 1.41 \\
\hline & February & Mar-May & 42 & 0.54 & 0.68 & -3.12 & 1.14 \\
\hline & March & Mar-May & 42 & 0.64 & 0.81 & -3.97 & 1.47 \\
\hline & April & May-Jul & 42 & 0.39 & 0.63 & -2.64 & 1.08 \\
\hline & May & May-Jul & 42 & 0.23 & 1.34 & -7.25 & 1.10 \\
\hline & June & Jul-Aug & 37 & -0.87 & 2.31 & -12.22 & 0.77 \\
\hline & July & Jul-Aug & 37 & -0.45 & 1.73 & -6.58 & 2.04 \\
\hline & August & Aug-Sep & 37 & -2.22 & 3.65 & -15.03 & 1.05 \\
\hline \multirow{9}{*}{ Wheat } & July & Jul-Sep & 42 & 0.73 & 0.49 & -0.70 & 1.45 \\
\hline & August & Sep-Dec & 42 & 0.91 & 0.48 & -1.16 & 1.47 \\
\hline & September & Sep-Dec & 42 & 0.96 & 0.47 & -0.42 & 1.54 \\
\hline & October & Dec-Mar & 42 & 0.61 & 0.52 & -0.90 & 1.32 \\
\hline & November & Dec-Mar & 42 & 0.53 & 0.66 & -1.41 & 1.27 \\
\hline & December & Dec-Mar & 42 & 0.47 & 0.74 & -1.97 & 1.37 \\
\hline & January & Mar-May & 42 & -0.57 & 1.19 & -2.60 & 1.20 \\
\hline & February & Mar-May & 42 & -0.51 & 1.34 & -3.66 & 1.27 \\
\hline & March & Mar-May & 42 & -0.17 & 1.42 & -4.35 & 1.86 \\
\hline
\end{tabular}


Table 3: Occurrences of Spreads as a Percent of Contemporaneous Costs-of-Carry, 1957-1999

\begin{tabular}{|c|c|c|c|c|c|c|c|c|}
\hline \multirow{2}{*}{ Month } & \multirow{2}{*}{ Spread } & \multirow{2}{*}{$\begin{array}{l}\text { No. } \\
\text { Obs. }\end{array}$} & \multicolumn{6}{|c|}{ Percent $(\%)$ of Market Spread to Cost-of-Carry } \\
\hline & & & $0<\%$ & $\begin{array}{l}0<\% \\
<0.25\end{array}$ & $\begin{array}{c}0.25<\% \\
<0.50\end{array}$ & $\begin{array}{c}0.50<\% \\
<0.75\end{array}$ & $\begin{array}{c}0.75<\% \\
<1.0\end{array}$ & $\%>1.0$ \\
\hline & Corn & & & & & & & \\
\hline Dec & Dec-Mar & 43 & 2 & 1 & 3 & 13 & 14 & 10 \\
\hline Jan & Mar-May & 43 & 1 & 1 & 8 & 6 & 17 & 10 \\
\hline Feb & Mar-May & 43 & 2 & 1 & 6 & 11 & 12 & 11 \\
\hline Mar & Mar-May & 43 & 4 & 1 & 2 & 8 & 6 & 22 \\
\hline Apr & May-Jul & 43 & 7 & 4 & 8 & 9 & 9 & 6 \\
\hline May & May-Jul & 43 & 10 & 7 & 8 & 6 & 5 & 7 \\
\hline Jun & Jul-Sep & 43 & 25 & 2 & 7 & 5 & 3 & 1 \\
\hline \multirow[t]{2}{*}{ Jul } & Jul-Sep & 43 & 21 & 4 & 2 & 9 & 5 & 2 \\
\hline & Soybeans & & & & & & & \\
\hline Nov & Nov-Jan & 42 & 2 & 3 & 5 & 10 & 9 & 13 \\
\hline Dec & Jan-Mar & 42 & 2 & 2 & 6 & 13 & 12 & 7 \\
\hline Jan & Jan-Mar & 42 & 3 & 2 & 4 & 10 & 14 & 9 \\
\hline Feb & Mar-May & 42 & 4 & 2 & 6 & 14 & 12 & 4 \\
\hline Mar & Mar-May & 42 & 3 & 3 & 3 & 10 & 13 & 10 \\
\hline Apr & May-Jul & 42 & 3 & 9 & 9 & 10 & 9 & 2 \\
\hline May & May-Jul & 42 & 8 & 4 & 7 & 8 & 11 & 4 \\
\hline Jun & Jul-Aug & 37 & 21 & 4 & 4 & 7 & 1 & 0 \\
\hline Jul & Jul-Aug & 37 & 17 & 3 & 6 & 3 & 7 & 1 \\
\hline \multirow[t]{2}{*}{ Aug } & Aug-Sep & 37 & 24 & 4 & 2 & 5 & 1 & 1 \\
\hline & Wheat & & & & & & & \\
\hline Jul & Jul-Sep & 42 & 3 & 4 & 6 & 5 & 9 & 15 \\
\hline Aug & Sep-Dec & 42 & 1 & 3 & 1 & 6 & 9 & 22 \\
\hline Sep & Sep-Dec & 42 & 3 & 0 & 3 & 4 & 11 & 21 \\
\hline Oct & Dec-Mar & 42 & 5 & 2 & 9 & 5 & 11 & 10 \\
\hline Nov & Dec-Mar & 42 & 8 & 4 & 4 & 5 & 10 & 11 \\
\hline Dec & Dec-Mar & 42 & 10 & 6 & 2 & 3 & 8 & 13 \\
\hline Jan & Mar-May & 42 & 26 & 2 & 1 & 6 & 5 & 2 \\
\hline Feb & Mar-May & 42 & 23 & 2 & 5 & 2 & 4 & 6 \\
\hline Mar & Mar-May & 42 & 19 & 1 & 5 & 2 & 6 & 9 \\
\hline
\end{tabular}


Table 4: Regressions of Spreads on U.S. Quarterly Grain Stocks, 1957-1999

\begin{tabular}{|c|c|c|c|c|c|c|c|}
\hline Commodity & Date & Spread & $\begin{array}{c}\text { Quarterly } \\
\text { Stocks }\end{array}$ & $\begin{array}{l}\text { No. } \\
\text { Obs. }\end{array}$ & $\beta_{0}$ & $\beta_{1}$ & $\mathrm{R}^{2}$ \\
\hline & Dec 1 & Dec-Mar & December & 43 & -41.10 & 5.56 & 0.16 \\
\hline & & & & & $(-2.36)^{* *}$ & $(2.74)^{* *}$ & \\
\hline \multirow[t]{6}{*}{ Corn } & Mar 1 & Mar-May & March & 43 & -36.07 & 4.96 & 0.14 \\
\hline & & & & & $(-2.24)^{* *}$ & $(2.54)^{* *}$ & \\
\hline & Jun 1 & Jul-Sep & June & 43 & -65.87 & 7.66 & 0.04 \\
\hline & & & & & $(-1.35)$ & $(1.23)$ & \\
\hline & Dec 1 & Nov-Jan & December & 42 & -28.07 & 5.07 & 0.15 \\
\hline & & & & & $(-2.13)^{* *}$ & $(2.71)^{* *}$ & \\
\hline \multirow[t]{6}{*}{ Soybeans } & Mar 1 & Mar-May & March & 42 & -35.91 & 6.47 & 0.14 \\
\hline & & & & & $(-2.10)^{* *}$ & $(2.50)^{* *}$ & \\
\hline & Jun 1 & Jul-Aug & June & 42 & -64.14 & 9.64 & 0.09 \\
\hline & & & & & $(-1.99)^{* *}$ & $(1.83)^{*}$ & \\
\hline & Sep 1 & Sep-Dec & September & 42 & -113.22 & 16.12 & 0.20 \\
\hline & & & & & $(-2.87)^{* *}$ & $(3.13)^{* *}$ & \\
\hline \multirow[t]{4}{*}{ Wheat } & Dec 1 & Dec-Mar & December & 42 & -74.67 & 10.79 & 0.07 \\
\hline & & & & & $(-1.63)$ & $(1.74)^{*}$ & \\
\hline & Mar 1 & Mar-May & March & 42 & -26.18 & 3.41 & 0.01 \\
\hline & & & & & $(-0.58)$ & $(0.54)$ & \\
\hline
\end{tabular}

Note: The estimated regression equation is Spread $_{t}=\beta_{0}+\beta_{1} \ln \left(Q S_{t}\right)+\varepsilon_{t}$, where $\ln \left(Q S_{t}\right)$ is the natural logarithm of U.S. quarterly stocks and $\varepsilon_{t}$ is the error term. The figures in parentheses are $t$-statistics with $* *$ indicating statistical significance at the $5 \%$ level, and $*$ statistical significance at the $10 \%$ level. 
Table 5: Simulation Results for Corn, 1957-1999

\begin{tabular}{|c|c|c|c|c|c|}
\hline Month & Spread & Strategy & $\begin{array}{l}\text { No. } \\
\text { Obs. }\end{array}$ & Mean & $\begin{array}{c}\text { Standard } \\
\text { Deviation }\end{array}$ \\
\hline & & Cash Sale & 3 & 275.59 & 45.06 \\
\hline \multirow[t]{3}{*}{ December } & Dec-Mar & Unhedged Storage & 3 & 276.33 & 46.06 \\
\hline & & Hedged Storage & 3 & 271.08 & 51.25 \\
\hline & & Cash Sale & 2 & 229.87 & 124.54 \\
\hline \multirow[t]{3}{*}{ January } & Mar-May & Unhedged Storage & 2 & 213.50 & 74.25 \\
\hline & & Hedged Storage & 2 & 236.38 & 142.31 \\
\hline & & Cash Sale & 3 & 215.05 & 69.53 \\
\hline \multirow[t]{3}{*}{ February } & Mar-May & Unhedged Storage & 3 & 223.00 & 55.75 \\
\hline & & Hedged Storage & 3 & 206.33 & 60.91 \\
\hline & & Cash Sale & 5 & 267.35 & 85.80 \\
\hline \multirow[t]{3}{*}{ March } & Mar-May & Unhedged Storage & 5 & 283.40 & 95.89 \\
\hline & & Hedged Storage & 5 & 256.83 & 70.23 \\
\hline & & Cash Sale & 11 & 242.20 & 87.67 \\
\hline \multirow[t]{3}{*}{ April } & May-Jul & Unhedged Storage & 11 & 244.73 & 93.11 \\
\hline & & Hedged Storage & 11 & 235.22 & 80.00 \\
\hline & & Cash Sale & 17 & 228.93 & 89.91 \\
\hline \multirow[t]{3}{*}{ May } & May-Jul & Unhedged Storage & 17 & 227.82 & 91.46 \\
\hline & & Hedged Storage & 17 & 219.55 & 85.63 \\
\hline & & Cash Sale & 27 & 214.76 & 85.15 \\
\hline \multirow[t]{3}{*}{ June } & Jul-Sep & Unhedged Storage & 27 & 197.89 & 77.64 \\
\hline & & Hedged Storage & 27 & 209.05 & 90.97 \\
\hline & & Cash Sale & 25 & 207.83 & 92.70 \\
\hline \multirow[t]{2}{*}{ July } & Jul-Sep & Unhedged Storage & 25 & 193.76 & 82.89 \\
\hline & & Hedged Storage & 25 & 197.11 & 84.32 \\
\hline
\end{tabular}


Table 6: Results of the Paired-Differences Tests for Corn, 1957-1999

\begin{tabular}{|c|c|c|c|c|c|c|}
\hline Month & Spread & $\begin{array}{c}\text { Paired } \\
\text { Difference }\end{array}$ & $\begin{array}{l}\text { No. } \\
\text { Obs. }\end{array}$ & Mean & $\begin{array}{l}\text { Standard } \\
\text { Deviation }\end{array}$ & $t$-Ratio \\
\hline \multirow{3}{*}{ December } & \multirow{3}{*}{ Dec-Mar } & CS-US & 3 & -0.74 & 8.57 & -0.15 \\
\hline & & CS-HS & 3 & 4.51 & 20.34 & 0.38 \\
\hline & & US-HS & 3 & 5.25 & 28.87 & 0.31 \\
\hline \multirow{3}{*}{ January } & \multirow{3}{*}{ Mar-May } & CS-US & 2 & 16.37 & 50.29 & 0.46 \\
\hline & & CS-HS & 2 & -6.50 & 17.76 & -0.52 \\
\hline & & US-HS & 2 & -22.88 & 68.06 & -0.48 \\
\hline \multirow{3}{*}{ February } & \multirow{3}{*}{ Mar-May } & CS-US & 3 & -7.95 & 13.94 & -0.99 \\
\hline & & CS-HS & 3 & 8.71 & 22.66 & 0.67 \\
\hline & & US-HS & 3 & 16.67 & 21.31 & 1.35 \\
\hline \multirow{3}{*}{ March } & \multirow{3}{*}{ Mar-May } & CS-US & 5 & -16.05 & 26.85 & -1.34 \\
\hline & & CS-HS & 5 & 10.53 & 20.84 & 1.13 \\
\hline & & US-HS & 5 & 26.58 & 42.90 & 1.39 \\
\hline \multirow{3}{*}{ April } & \multirow{3}{*}{ May-Jul } & CS-US & 11 & -2.53 & 34.08 & -0.25 \\
\hline & & CS-HS & 11 & 6.99 & 29.24 & 0.79 \\
\hline & & US-HS & 11 & 9.51 & 54.77 & 0.58 \\
\hline \multirow{3}{*}{ May } & \multirow{3}{*}{ May-Jul } & CS-US & 17 & 1.11 & 21.74 & 0.21 \\
\hline & & CS-HS & 17 & 9.38 & 15.24 & $2.54^{*}$ \\
\hline & & US-HS & 17 & 8.27 & 27.90 & 1.22 \\
\hline \multirow{3}{*}{ June } & \multirow{3}{*}{ Jul-Sep } & CS-US & 27 & 16.87 & 32.34 & $2.71 *$ \\
\hline & & CS-HS & 27 & 5.72 & 48.89 & 0.61 \\
\hline & & US-HS & 27 & -11.16 & 55.05 & -1.05 \\
\hline \multirow{3}{*}{ July } & \multirow{3}{*}{ Jul-Sep } & CS-US & 25 & 14.07 & 26.85 & $2.62 *$ \\
\hline & & CS-HS & 25 & 10.72 & 16.62 & $3.23 *$ \\
\hline & & US-HS & 25 & -3.35 & 28.69 & -0.58 \\
\hline
\end{tabular}

Note: CS-US denotes the paired difference of net returns between the cash sale (CS) and unhedged storage (US), CS-HS denotes the paired difference of net returns between the cash sale (CS) and hedged storage (HS), and US-HS denotes the paired difference of net returns between the unhedged storage (US) and hedged storage (HS). The $t$-ratio is $t=\frac{\bar{d}-0}{\sqrt{s_{D}^{2} / n}}$, where $\bar{d}$ is the average of the paired differences $\left(d_{i}\right)$ of the net returns between two marketing strategies, $n$ is the number of paired differences, and $s_{D}^{2}=\frac{\sum_{i=1}^{n} d_{i}^{2}-\frac{1}{n}\left(\sum_{i=1}^{n} d_{i}\right)^{2}}{n-1}$. 
Table 7: Regressions of Actual Returns to Storage on the Predicted Returns to Storage, 1957-1999

\begin{tabular}{|c|c|c|c|c|c|}
\hline Commodity & $\begin{array}{c}\text { Returns to } \\
\text { Storage }\end{array}$ & No. Obs. & $\beta_{0}$ & $\beta_{1}$ & $\mathrm{R}^{2}$ \\
\hline \multirow{4}{*}{ Corn } & Unhedged & 93 & 5.49 & 0.68 & 0.25 \\
\hline & (US-CS) & & $(0.95)$ & $(3.80)^{*}$ & \\
\hline & Hedged & 93 & 4.16 & 0.52 & 0.08 \\
\hline & (HS-CS) & & $(0.63)$ & $(2.52)^{*}$ & \\
\hline \multirow{4}{*}{ Soybeans } & Unhedged & 123 & 14.10 & 1.13 & 0.27 \\
\hline & (US-CS) & & $(1.02)$ & $(3.41)^{*}$ & \\
\hline & Hedged & 123 & 6.24 & 1.66 & 0.27 \\
\hline & (HS-CS) & & $(0.55)$ & $(6.00)^{*}$ & \\
\hline \multirow{4}{*}{ Wheat } & Unhedged & 122 & 2.92 & 0.40 & 0.10 \\
\hline & (US-CS) & & $(0.28)$ & $(0.96)$ & \\
\hline & Hedged & 122 & 9.59 & 1.64 & \\
\hline & (HS-CS) & & $(1.42)$ & $(5.99)^{*}$ & 0.32 \\
\hline
\end{tabular}

Note: US-CS denotes the difference of net returns between unhedged storage (US) and cash sale (CS), i.e., actual returns to unhedged storage, and HS-CS denotes the difference of net returns between hedged storage (HS) and cash sale (CS), i.e., actual returns to hedged storage. 
Figure 1. Spread As a Percent of Cost-of-Carry for Corn, 1957-1999

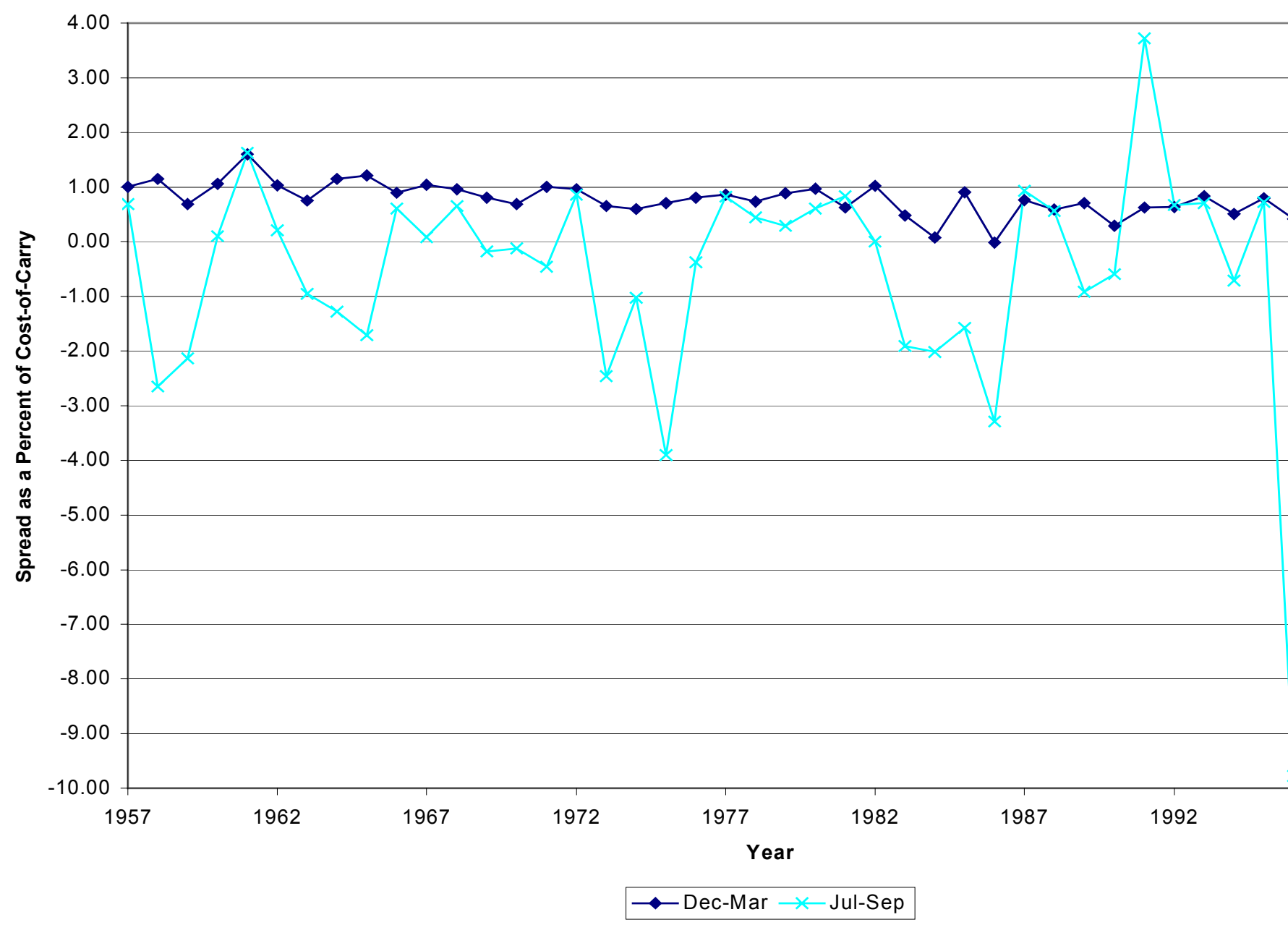

Note: The Dec-Mar spread is observed on December 1, and the Jul-Sep Spread is observed on July 1. 
Figure 2. Spread As a Percent of Cost-of-Carry for Soybeans, 1958-1999

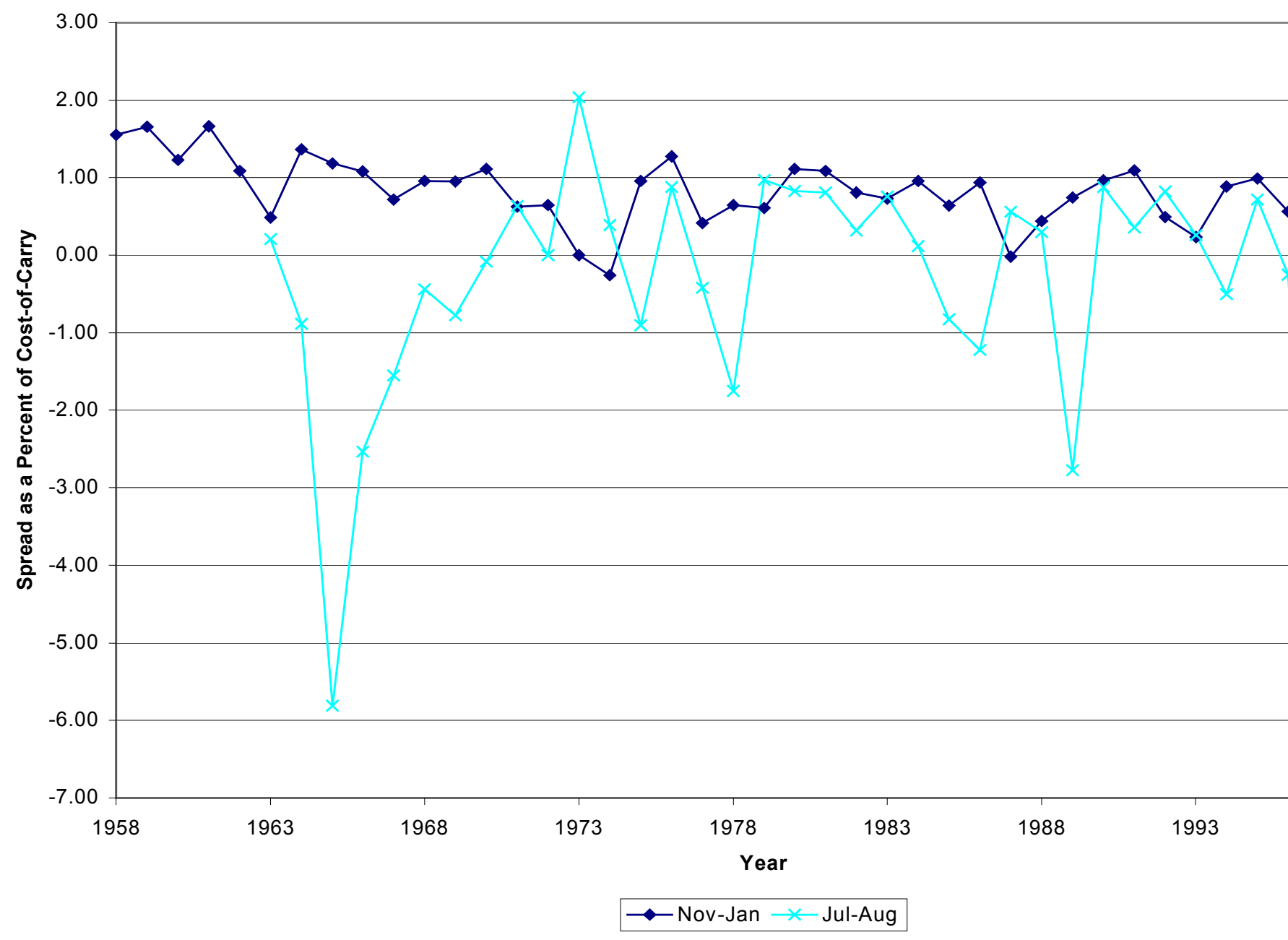

Note: The Nov-Jan spread is observed on November 1, and the Jul-Aug spread is observed on July 1. 
Figure 3. Spread As a Percent of Cost-of-Carry for Wheat, 1958-1999

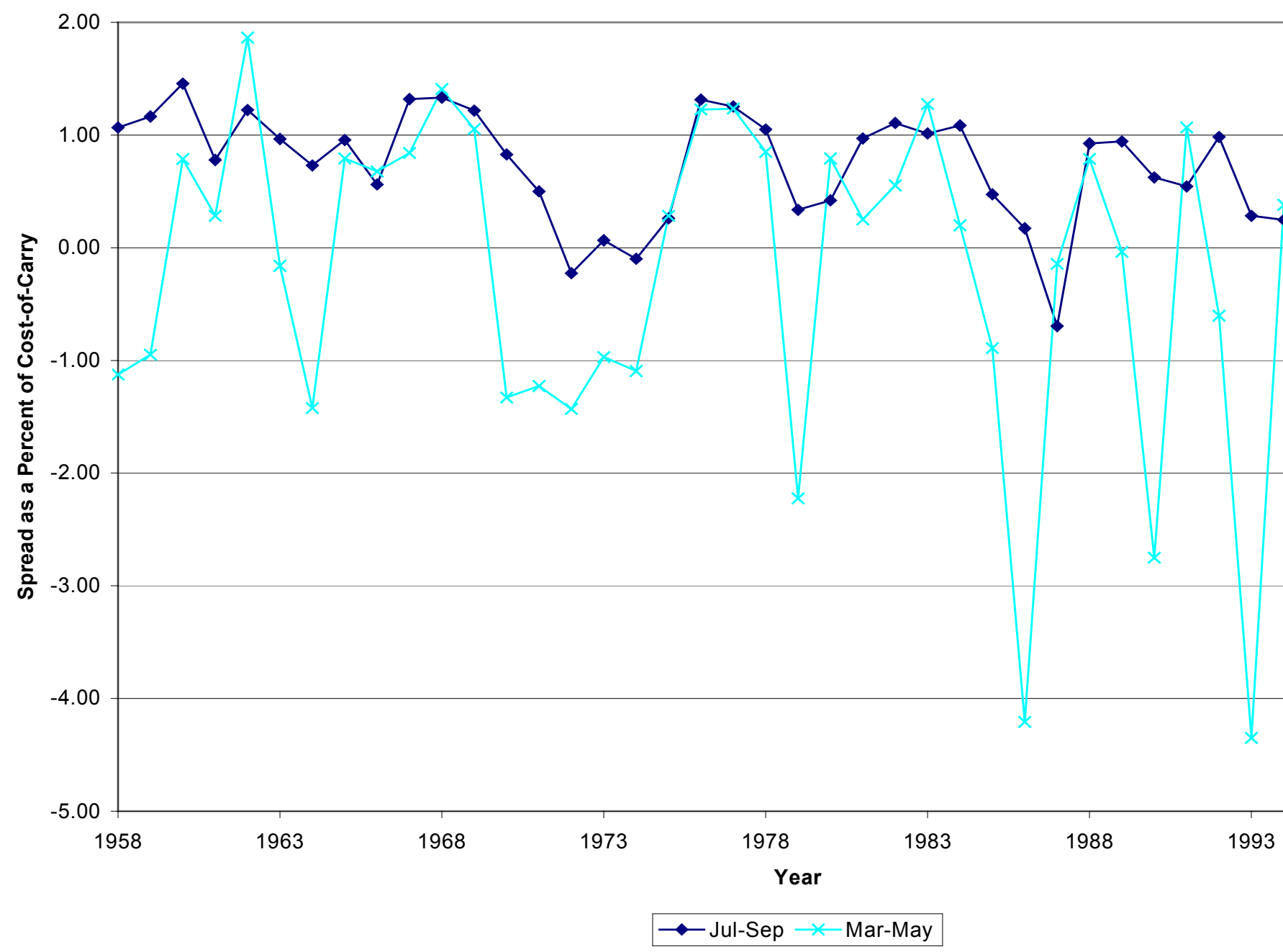

Note: The Jul-Sep spread is observed on July 1, and the Mar-May spread is observed on March 1. 


\section{References}

Benirschka, M., and J. Binkley. "Optimal Storage and Marketing over Space and Time." American Journal of Agricultural Economics 77(August 1995): 512-24.

Brennan, M. J. “The Supply of Storage.” American Economic Review 48(1958): 50-72.

. "The Price of Convenience and the Pricing of Commodity Contingent Claims," in Stochastic Models and Options Values, D. Lund and B. Oksendal (Editors), New York: Elsevier Science Publishers B.V., 1991.

Brennan, D., J. Williams, and B.D. Wright. "Convenience Yield without the Convenience: A Spatial-Temporal Interpretation of Storage under Backwardation.” Economic Journal 107(July 1997): 1009-22.

Cho, D.W., and G.S. McDougall. "The Supply of Storage in Energy Futures Markets." Journal of Futures Markets 10(1990): 611-621.

Fama, E.F., and K.R. French. "Commodity Futures Prices: Some Evidence on Forecast Power, Premiums, and the Theory of Storage." Journal of Business 60(January 1987): 55-74.

. "Business Cycles and the Behavior of Metal Prices." Journal of Finance 43( December 1988): 1075-1093.

Federal Reserve Bank of St. Louis, U.S. Financial Data. Weekly Issues, 1982-1999.

Fischer, G.C. The Prime: Myth and Reality. Philadelphia: Temple University Press, 1982.

Frechette, D.L., and P.L. Fackler. "What Causes Commodity Price Backwardation?" American Journal of Agricultural Econmics 81(November 1999): 761-771.

Gray, R.W., and A.E. Peck. "The Chicago Wheat Futures Market: Recent Problems in Historical Perspective.” Food Research Institute Studies 18(1981): 89-115.

Heaney, R. "A Test of the Cost-of-Carry Relationship Using the London Metal Exchange Lead Contract.” Journal of Futures Markets 18(April 1998): 177-200.

Hurt, C. "Listen to the Market.” Unpublished working paper, Purdue University, 1987.

Jackson, T.E., S.H. Irwin, and D.L. Good. "1996 Pricing Performance of Market Advisory Services for Corn and Soybeans.” AgMAS Project Research Report 1997-02, December 1997. Department of Agricultural and Consumer Economics, University of Illinois at Urbana-Champaign. 
Kahneman, D., P. Slovic, and A. Tversky. Judgment under Uncertainty: Heuristics and Biases. Cambridge: Cambridge University Press, 1982.

Kahneman, D., and M.W. Riepe. “Aspects of Investor Psychology.” Journal of Portfolio Management 24(1998).

Kaldor, N. "Speculation and Economic Stability." Review of Economic Studies 7(October 1939): 1-27.

Keynes, J.M. A Treatise on Money, vol 2. New York: Harcourt, 1930.

Kolb, R.W. Futures, Options, and Swaps, 3rd ed. Malden: Blackwell Publishers Inc., 1999.

Mahnke, J.L. "Price Determination and Efficiency of Intermonth Corn, Wheat and Soybean Futures Price Spreads.” Unpublished M.S. Thesis, Purdue University, 1985.

Telser, L.G. "Futures Trading and the Storage of Cotton and Wheat." Journal of Political Economy 66(June 1958): 233-55.

Thompson, S. "Returns to Storage in Coffee and Cocoa Futures Markets." Journal of Futures Markets 6(1986): 541-564.

Weymar, F.H. "The Supply of Storage Revisited." American Economic Review 39(December 1949): 1226-1234.

Williams, J.C., and B.D. Wright. Storage and Commodity Markets. New York: Cambridge University Press, 1991.

Working, H. "Price Relations between May and New-Crop Wheat Futures at Chicago since 1885." Wheat Studies of Food Research Institute 10(February 1934): 183228.

. "Theory of the Inverse Carrying Charge in Futures Markets." Journal of Farm Economics 30(February 1948): 1-28.

. "The Theory of Price of Storage." American Economic Review 39(May 1949): 1254-62.

Wright, B.D., and J.C. Williams. "A Theory of Negative Prices for Storage." Journal of Futures Markets 9(February 1989): 1-13. 
Zulauf, C.R., and S.H. Irwin. "Market Efficiency and Marketing to Enhance Income of Crop Producers." Review of Agricultural Economics 20(Fall/Winter 1998): 308331. 